\title{
Neochloris oleoabundans from nature to industry: a comprehensive review
}

\author{
Carl Safi $\cdot$ Antonino Pollio · Giuseppe Olivieri
}

Received: 5 July 2021 / Accepted: 16 September 2021/Published online: 24 September 2021

(C) The Author(s) 2021

\begin{abstract}
Microalgae technology has been extensively studied during the last two decades. Thousands of species were isolated, and few are currently used in the market for multiple purposes. The current comprehensive review focuses on a promising species named Neochloris oleoabundans. It encompasses a historical overview of the species followed by a detailed description of its taxonomy, ecophysiology and morphology. Furthermore, a thorough screening is conducted to outline the production conditions employed to grow the microalga. In addition, multiple cell disruption and fractionation methods previously applied on $N$. oleoabundans are described and discussed together with the value chain creation after applying all the unit operations.
\end{abstract}

Keywords Neochloris Oleoabundans · Cell wall · Morphology $\cdot$ Cell disruption · Fractionation · Biorefinery

C. Safi $(\bowtie)$

Wageningen Food \& Biobased Research, PO Box 17, 6700 AA Wageningen, The Netherlands

e-mail: carl.safi@wur.nl

\section{A. Pollio}

Department of Biology, University of Naples Federico II, via Cinthia 4, 80126 Naples, Italy

\section{G. Olivieri}

Bioprocess Engineering, AlgaePARC, Wageningen University, PO Box 16, 6700 AA Wageningen, The

Netherlands

\section{Introduction}

Microalgae have played a capital role during the process of evolution of life on earth. About 3.7 billion years ago, the Earth's atmosphere was composed of water vapor, ammonia, hydrogen, $\mathrm{CO}_{2}$ and methane gas. Hence, an atmosphere that is unlikely to support any kind of life. Fossil records indicated that a microscopic organism emerged in the primordial soup (theory of the origin of life on earth) and initiated the extraordinary process of photosynthesis, and released the oxygen molecule to the atmosphere. From that moment, algal cells had begun their three billion years journey toward a drastic atmospheric transformation from the harsh environment-that does not sustain life- to an oxygen-rich atmosphere that gave birth to plants during the Paleozoic Era 450 million years ago (Chapman and Waters 2002; Safi et al. 2014; Avagyan 2021). The journey was full of obstacles due to the brutal environment in which these species were evolving. Therefore, the first algae cells evolved and diversified millions of times in order to adapt, thrive and survive. Furthermore, according to paleobotanist Russell Chapman, "the first algae that managed to gain residence on terra firma must have come from freshwater, not the sea". Chapman also said, "even though four distinct types of algae managed to come ashore, only one of them evolved enough complexity to eventually cover the land with vegetation, what we 
now call trees, shrubs, flowers, and grass" (Daily Mail 2001).

Despite the lack of major breakthroughs during the last few years, microalgal technology is still gaining interest every year, and due to their large diversity, it is plausible to provide a detailed overview on the promising species. Microalgae represent a large diversity that accounts for more than one million species (Barsanti and Gualtieri 2010), among them an interesting species called Ettlia oleoabundans, also known as N. oleoabundans (Komàrek et al. 1989). It is a unicellular freshwater green species (Gatenby et al. 2003) that belongs to the class of Chlorophyceae.

So far, available reviews focused on microalgae in general, which provide limited information on the potential of each specific species. Only one review considered a detailed overview on a well-known species called Chlorella vulgaris (Safi et al. 2014). Therefore, the following review provides an in-depth overview of $N$. oleoabundans by describing its morphology, taxonomy, biochemical composition, ecophysiology and also explains the reproductive process of the cells. Furthermore, it highlights the applicative potential of $N$. oleoabundans focusing on production methods and other unit operations applied on this species to fractionate its valuable components.

\section{Taxonomy}

Between 1958 and 1960, seven new Neochloris species were described based on morphological attributes, cell dimensions, cell wall thickening, number of nuclei, position of pyrenoid and the kind of zoospores produced (Arce and Bold 1958; Bold 1958; Herndon 1958). Subsequently, Archibald (1973), described five new Neochloris species and provided a morphological key to all species (Archibald 1973). N. oleoabundans was first isolated sometime between 1958-1962 from the top of a sand dune $\left(2^{\circ} \mathrm{N} ; 55^{\circ} \mathrm{E}\right)$ in Rub al Khali in Saudi Arabia and named by Bold and Chantanachat (1962). It displayed the following characters: spherical cells, with a variable size, with a thin and smooth cell wall, single nucleus, parietal and cup-like chloroplast, two elongate pyrenoids, ovoid zoospores with two isokont flagella. Moreover, the authors reported that 3-weeks old cultures produced a considerable amount of oil droplets that coalesced in a single large drop during the following weeks, thereby confining the chloroplast at one pole of the cell.

The use of ultrastructural and molecular characterisation, together with the continuous description of new taxa, has led to a deep taxonomical revision of many genera, including Neochloris. Starr (1955) erected the new genus Neochloris, which is morphologically close to Chlorococcum, due to the following diagnostic features: the occurrence of naked zoospores with isokont flagella, a hollow spherical chloroplast, and the presence of at least one pyrenoid in the chloroplast of vegetative cells. The type species, Neochloris aquatica, isolated from an aquarium of Indiana University, was multinucleate and showed an eccentric position of the pyrenoid (Starr 1957).

Its name was changed by Riří Komárek in 1989 after conducting advanced taxonomic studies which led to its classification into a new special genus named Ettlia (zoosporine Chlorellales). The genus Neochloris was subsequently split in two by Komarek (1989) who maintained the multinucleate species in Neochloris, transferring the uninucleate species in the new genus Ettlia. In the same year, Watanabe and Floyd (1989) proposed a taxonomic treatment of the genus, that was based on comparative ultrastructure, ending in three groups (Watanabe and Floyd 1989). The authors did not include in the study N. oleoabundans, but erected the new genus Chlorococcopsis with two species Neochloris wimmeri and Neochloris minuta whose morphological and ultrastrucutural characters are closely related to $N$. oleoabundans (Watanabe and Floyd 1989). Subsequently, Deason et al. (1991) tried to unify the taxonomic treatments proposed by Komarek (1989) and Watanabe and Floyd (1989), suggesting a different circumscription of the genera Neochloris and Ettlia, and acknowledging the priority of the name Ettlia over Chlorococcopsis, that was abandoned (Deason et al. 1991).

However, the phylogenetic relationships of the Ettlia species have been analysed on the basis of $18 \mathrm{~S}$ rDNA (Pegg et al. 2015). Results have shown that if $E$. carotina is the typical species of the genus, the other three taxa included in Ettlia should be assigned to other genera (Pegg et al. 2015). E. oleoabundans is clearly separated from the other Ettlia species and is in a closer phylogenetic relation with taxa belonging to Micractinium and Actinastrum, members of family Chlorellaceae (Chlorellales, Trebouxiophyceae). Given these results, a taxonomic reassignment of $E$. 
oleoabundans was required. Indeed, the most common name used nowadays in the literature is $N$. oleoabundans (UTEX 1185) instead of Ettlia oleoabundans (UTEX 1185) (Gatenby et al. 2003; Baldisserotto et al. 2014; Castro-Puyana et al. 2013; Li et al. 2008; Morales-Sánchez et al. 2013; Murray et al. 2011; Villa et al. 2014; Wang and Lan 2011).

\section{Cell morphology}

Cell morphology changes with respect to growth conditions applied for cell growth. In general, $N$. oleoabundans has a spherical shape with a diameter of 3-6 $\mu \mathrm{m}$ (Chantanachat and Bold 1962; Baldisserotto et al. 2014). The large part of its cytoplasm is occupied by a cup-shaped parietal chloroplast that embeds the thylakoids and a large pyrenoid. The latter is surrounded by a shell of starch granules, and it is crossed by one or two thylakoids (Baldisserotto et al. 2014; Giovanardi et al. 2013). The pyrenoid contains high levels of Ribulose-1,5-bisphosphate carboxylase oxygenase ( $\mathrm{RuBisCO})$ and is the centre of carbon dioxide fixation (Safi et al. 2014). N. oleoabundans has a single nucleus that contains one nucleolus (Castro-Puyana et al. 2013), and has one or two mitochondria (Giovanardi et al. 2013). During cell maturation, cytoplasmic vacuolisation occurs and keeps increasing until four weeks of growth by compressing the cytoplasm at the periphery of the cells (Baldisserotto et al. 2012; Giovanardi et al. 2013).

\section{Ecophysiology}

$N$. oleoabundans reproduces asexually through formation of zoospores or aplanospores. To our knowledge, sexual reproduction has not been observed in $N$. oleoabundans (Chantanachat and Bold 1962). Zoospores are biflagellate and measure between 2 and $3.5 \mu \mathrm{m}$ in width and 3.6 and $4.5 \mu \mathrm{m}$ in length (Deason et al. 1991). The flagella allow them to swim to a favourable environment in which they can develop and mature. Zoospores form vegetative spherical cells after a short period of time, and lack a well-defined cell wall (Arce and Bold 1958; Deason et al. 1991). Nevertheless, zoospores fail sometimes to become motile and begin to mature within the confine of their sporangium until rupturing it after maturation. These new born cells are aplanospores (Arce and Bold 1958), which accumulate in considerable numbers before they are liberated by rupturing the cell wall of the sporangium.

Their morphological simplicity has led to an undervaluation of their biological diversity, but different species not phylogenetically related are present in desert crusts, evidencing that the resistance to water stress is largely diffused among green algae (Gray et al. 2007). Chlorophyta from arid environments can modulate their osmotic balance either by expelling salts from the cell or accumulating compatible solutes, and can also counteract water loss by aggregating cells to colonies, producing extracellular polymeric substances (EPS) or reinforcing the cell wall with a sporopollenin layer (Bertuzzi et al. 2017). $N$. oleoabundans was isolated from the sand dunes of Rub al Khali desert, a hyper-arid environment where rainfalls are very scarce and water is available as dew, fog, humidity (Henschel and Seely 2008). Present knowledge on $N$. oleoabundans world distribution is very scanty, and it is not known if this species can be considered endemic to desert environments. Apparently, all the recent studies carried out on the biotechnological potential of this alga rely on the strain UTEX 1185. The continuous environmental changes that $N$. oleoabundans daily endures in its habitat accounts for its flexibility: freshwater or sea water can be used for its cultivation, and the alga can grow either in mixotrophic or heterotrophic conditions (Baldisserotto et al. 2016).

$N$. oleoabundans has a high growth rate (Gouveia et al. 2009), and showed an adaptive capacity to grow in marine water (Popovich et al. 2012), which is convenient for sustainable production. This ability can be explained by taking into consideration the peculiar habitat of this alga: the desert sand. Water shortage, in turn, induces matric and osmotic stresses that require adaptation strategies. A matric stress is defined as the direct contact with dry air, whereas a hyperosmotic stress occurs when cells are still submerged in a water solution (Billi and Potts 2000). In the first case, the dehydration is more rapid and severely affects the physiological machinery of cells (Gustavs et al. 2010).

The cellular activities triggered by the contemporary occurrence of different stresses are not fully understood: de Jaeger et al. (2018) report that under salt stress, proline is accumulated by $N$. oleoabundans, and that anti-oxidate pathways are activated to defend 
the cells from oxidative stresses (de Jaeger et al. 2018). Moreover, also $\mathrm{pH}$ plays an important role, and values equal to 9.5 can mitigate stress effects (Peng et al. 2017). The lipid content is related to stress conditions and the occurrence of both nutrient starvation and high temperature stimulated by $66 \%$ the lipid production in laboratory tests carried out on $N$. oleoabundans (Kwak et al. 2015).

\subsection{1 Cell wall}

$N$. oleoabundans grown under normal growth conditions has a rigid 2-layered cell wall (200 nm thick) mainly composed of $24.3 \%$ carbohydrates, $22.2 \%$ lipids, $31.5 \%$ proteins, and $7.8 \%$ inorganic materials (Wang et al. 2015; Rashidi and Trindade 2018). Nevertheless, the composition of the cell wall is directly correlated to the growth conditions employed to grow the cells. It has been established that the cell wall thickness of Chlorella sp. - which has similar morphological characteristics as $N$. oleoabundans increased by $70 \%$ while grown under nitrogen deplete (ND) conditions (Yap et al. 2016). Moreover, the cell wall $N$. oleoabundans showed a significant increase in the concentration of carbohydrates when the microalga was grown under ND conditions (Rashidi et al. 2019). However, due to the scarcity of information in the literature about the physiological transformation of the cell wall of $N$. oleoabundans when grown in harsh conditions, it is plausible to consider the conclusion obtained on Nannochloropsis salina (Jeong et al. 2017). The latter concluded that the increase in the thickness of the microalga subjected to nitrogen deprivation is associated with the up-regulation of genes encoding for cellulose biosynthetic enzymes (Jeong wt al. 2017), which leads to the accumulation of cellulose in the cell wall, thereby increase in rigidity.

\subsection{2 Biochemical composition}

The etymology of $N$. oleoabundans (Table 1) reflects the main reason scientists were initially interested in this species as it has the capacity to accumulate up to $55 \%$ lipids on a dry weight basis (Tornabene et al. 1983; Li et al. 2008; Pruvost et al. 2009; Popovish et al. 2012) when grown under stress conditions. This large amount of lipids and more precisely triglycerides has attracted the attention of scientists to convert these lipids into biodiesel (Avagyan 2018; Avagyan and Singh 2019). Nevertheless, $N$. oleoabundans composition is dependent on environmental factors in spite of its capacity to grow in harsh conditions, and/or to grow in marine or fresh water (Safi et al. 2020). Table 2 displays the primary composition of $N$. oleoabundans when grown under Nitrogen Replete (NR) or Nitrogen Deplete (ND) conditions. It can be observed that under nitrogen replete conditions, protein content increases up to $\pm 55 \% \cdot \mathrm{dw}^{-1}$, whereas under nitrogen deplete conditions lipid content increases up to $\pm 60 \% \cdot \mathrm{dw}^{-1}$ and protein content decreases significantly. This indicates that during nitrogen starvation the cells undergo biosynthesis changes and major ultrastructural changes such as chloroplast shrinkage and cell wall transformations (Sinetova et al. 2006). The shortage of nitrogen in the medium forces the cells to search for alternative sources of nitrogen by releasing nitrogen from the photosynthetic pigments such as chlorophyll, and utilize the same for the metabolic processes (Praveenkumar et al. 2012). Consequently, this leads to a cellular metabolic flux due to the decline in the rate of photosynthesis (Courchesne et al. 2009), and therefore, NADH would accumulate. Subsequently, the enzyme citrate synthase is inhibited and acetyl CoA seizes from entering the Kerbs cycle. The increase in the level of acetyl $\mathrm{CoA}$ would lead to the activation of acetyl CoA carboxylase, which in turn would convert acetyl CoA in to malonyl CoA (Praveenkumar et al. 2012). As a result, lipid synthesis increases resulting in significant storage lipid accumulation (Mandal and Mallick 2009), mainly composed of TAG (Table 2).

The fatty acid composition contains a range of saturated, monounsaturated and polyunsaturated fatty acids (Table 3). Similar to the aforementioned components, the fatty acid profile varies based on the growth conditions. However, regardless of the growth conditions employed, the predominant fatty acids are C16:0, C18:0, C18:1, C18:2 and C18:n3.

\section{5. Production}

The interest in the cultivation of Neochloris strains has significantly increased over the last decade due to its potential to treat wastewater treatment (Altunoz et al. 2020; Singh et al. 2020), to accumulate significant amounts of lipids suitable for biodiesel production 
Table 1 Etymology and explanation of the former name of E. oleoabundans

\begin{tabular}{|c|c|c|c|c|}
\hline & \multicolumn{4}{|c|}{ N. Oleoabundans Etymology } \\
\hline & Greek & Latin & Meaning & Remarks \\
\hline $\mathrm{NeO}$ & Neos $(v \varepsilon \hat{c} o \varsigma)$ & N/A & New & Due to its high concentration in chlorophyll \\
\hline Chloris & 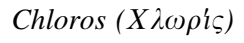 & N/A & Green & \\
\hline Oleo & N/A & Oleum & Oil & Due to its capacity to accumulate large amounts of lipids \\
\hline Abundans & N/A & Abundo- & Overflowing & \\
\hline
\end{tabular}

(Banerjee et al. 2019), and its capacity to capture a substantial amount of $\mathrm{CO}_{2}$ (Zhu et al. 2018; Sepulveda et al. 2019). In addition, the capacity of Neochloris to grow in fresh and marine medium has increased the interest in exploring its full potential (Safi et al. 2020). Indeed, multiple production methods can be employed to grow microalgae with mitigated rate of efficacy. Among the methods are open ponds and photobioreactors in which the species can be grown under heterotrophic, autotrophic and mixotrophic conditions (Avagyan 2010; Avagyan AB 2013; Avagyan 2018;). However, the effect of important operating conditions, such as light supply, nitrogen supply, medium composition and temperature play a crucial role in the healthy growth of $N$. oleoabundans and therefore these parameters have been extensively investigated over the last decade.

Jazzar et al., (2016) investigated the effect of nitrate and phosphate concentration on cultivation under indoor autotrophic batch cultivation in $1.8 \mathrm{~L}$ bubble column photobioreactor. The largest biomass productivity $\left(0.115 \mathrm{~g} \mathrm{~L}^{-1}\right.$ day $\left.^{-1}\right)$ and concentration $\left(1.69 \mathrm{~g} \mathrm{~L}^{-1}\right)$ were achieved in nitrate $\left(0.99 \mathrm{~g} \mathrm{~L}^{-1}\right)$ and phosphate $\left(0.085 \mathrm{~g} \mathrm{~L}^{-1}\right)$ rich medium at $23^{\circ} \mathrm{C}$ and $200 \mu \mathrm{E} \mathrm{m}^{-2} \mathrm{~s}^{-1}$ light flux. However, lipid productivity $\left(0.036 \mathrm{~g} \mathrm{~L}^{-1}\right.$ day $^{-1}$ ) and percentage within biomass $(44 \%)$ were instead triggered in nitrate $\left(0.074 \mathrm{~g} \mathrm{~L}^{-1}\right)$ and phosphate $\left(0.016 \mathrm{~g} \mathrm{~L}^{-1}\right)$ deficient medium. Other (MoralesSánchez et al. 2013, 2014) carried out similar investigations, but under heterotrophic conditions, and by separating the biomass growth from the lipid accumulation phase. Thus, the biomass was heterotrophically cultivated ( $10 \mathrm{~g} \mathrm{~L}^{-1}$ glucose) batch-wise in a 20 $\mathrm{L}$ reactor under sufficient nitrogen supply, followed by the addition of $10 \mathrm{~L}$ medium under limited nitrogen condition and then a final resting phase with no further addition of medium. Consequently, due to the organic carbon supply, a larger biomass concentration was achieved (5.6 $\left.\mathrm{g} \mathrm{L}^{-1} \mathrm{day}^{-1}\right)$ at the end of the fed-batch. Moreover, at the end of the resting phase, lipid productivity and percentage of the biomass were $1.9 \mathrm{~g}$ $\mathrm{L}^{-1} \mathrm{day}^{-1}$ and $54 \%$, respectively. Accordingly, the accumulation of lipid is often associated to the switch of the metabolism first from biomass to starch synthesis and then to lipid synthesis (Klok et al. 2013a; Morales-Sánchez et al. 2013, 2014; Baldisserotto et al. 2016).

Nonetheless, despite the fact that lipid synthesis and biomass growth are often considered decoupled, Klok et al. (2013a) proved that it is possible to simultaneously produce both in a continuous process. The production was therefore conducted in a $1.7 \mathrm{~L}$ flat panel turbidostat for autotrophic cultivation at a two inlet light fluxes (200 and $500 \mu \mathrm{E} \mathrm{m}^{-2} \mathrm{~s}^{-1}$ ). The system was run as a turbidostat, by adjusting the dilution on the basis of the light absorption. Biomass and lipid productivity ranged $0.26-1.29 \mathrm{~g} \mathrm{~L}^{-1}$ day $^{-1}$ and 0.011 $0.049 \mathrm{~g} \mathrm{~L}^{-1} \mathrm{day}^{-1}$, respectively, while lipid content ranged 1.5 to $12.4 \%$. The results were followed by a general metabolic model to demonstrate the possibility to customise the biomass composition on the basis of the dilution rate and inlet light flux Klok et al. (2013b). This was an important step to distinguish between nitrogen limited supply and completely depleted cultivation conditions, which is in agreement with the results obtained by Bona et al., (2014) in a semi-continuous cultivation condition (Bona et al. 2014).

Very few studies coupled the effect of nitrogen supply with the $\mathrm{pH}$ level in the culture. Therefore, it is worthwhile mentioning the study of Santos et al., (2014) because it showed that a step-wise increase of $\mathrm{pH}$ from the value taken during the growth $(\mathrm{pH}=8)$ to the value controlled during nitrogen starvation $(\mathrm{pH}=10)$ can optimise the lipid content up to $42 \%$, while an initial level of $10-12 \%$ was measured during 
Table 2 Biochemical composition of $N$. oleoabundans grown in nitrogen deplete and replete conditions

\begin{tabular}{|c|c|c|c|}
\hline \multirow[b]{2}{*}{ Components } & \multicolumn{3}{|c|}{ Biochemical composition } \\
\hline & N-Replete & N-Deplete & Reference \\
\hline $\begin{array}{l}\text { Proteins }\left(\% . \mathrm{dw}^{-1}\right) \\
\text { (Suarez Ruiz et al., 2020a) } \\
\text { (Günerken et al., 2016); } \\
\text { (Tibbetts et al., 2015); } \\
\text { (Morales-Sánchez et al., 2014); } \\
\text { (Garibay-Hernández et al., 2013); } \\
\text { (Popovich et al., 2012) }\end{array}$ & $27-55$ & $17-26$ & (Safi et al., 2020); \\
\hline $\begin{array}{l}\text { Carbohydrates }\left(\% . \mathrm{dw}^{-1}\right) \\
\text { (Günerken et al., 2016); } \\
\text { (Tibbetts et al., 2015); } \\
\text { (Morales-Sánchez et al., 2014) } \\
\text { (Sun et al., 2014); } \\
\text { (Garibay-Hernández et al., 2013); } \\
\text { (Popovich et al., 2012) }\end{array}$ & $15-41$ & $17-44$ & (Suarez Ruiz et al., 2020a); \\
\hline $\begin{array}{l}\text { Lipids }\left(\% \cdot \mathrm{dw}^{-1}\right) \\
\text { (Suarez Ruiz et al., 2020a); } \\
\text { (Chungjatupornchai et al., 2019); } \\
\text { (Günerken et al., 2016); } \\
\text { (Tibbetts et al., 2015); } \\
\text { (Sun et al., 2014); } \\
\text { (Garibay-Hernández et al., 2013); } \\
\text { (Popovich et al., 2012); } \\
\text { (Tornabene et al., 1983) }\end{array}$ & $8-36$ & $36-60$ & (Safi et al., 2020); \\
\hline $\begin{array}{l}\text { TAG (\%/total lipids) } \\
\text { (Sun et al., 2014); } \\
\text { (Morales-Sánchez et al., 2014); } \\
\text { (Popovich et al., 2012); } \\
\text { (Tornabene et al., 1983) }\end{array}$ & $9-19$ & $21-80$ & (Günerken et al., 2016); \\
\hline $\begin{array}{l}\text { Glycolipids (\%/total lipids) } \\
\text { (Sun et al., 2014); } \\
\text { (Popovich et al., 2012) }\end{array}$ & $4-6$ & $4-7$ & (Günerken et al., 2016); \\
\hline $\begin{array}{l}\text { Phospholipids (\%/total lipids) } \\
\text { (Sun et al., 2014); } \\
\text { (Popovich et al., 2012) }\end{array}$ & $1-11$ & $2-12$ & (Günerken et al., 2016); \\
\hline
\end{tabular}

the growth at nitrogen sufficient conditions (Santo et al. 2014).

Another important parameter affects the biomass growth and lipid productivity: the supply of light. An extensive characterization of the dynamic of biomass composition of $N$. oleoabundans on the basis of the dynamic of light supply under different circadian cycles has been conducted in multiple studies (de
Winter et al. 2013; de Winter et al. 2014; de Winter et al. 2017a, b). The studies found that the duplication of Neochloris cells is naturally synchronised on a circadian cycle, despite the fact that the biomass was grown in a continuous flat panel photobioreactor operated as a turbidostat, and under constant light conditions. Small variations of the lipid content were also observed during the $24 \mathrm{~h}$ cell cycle, both at 
Table 3 Fatty acid composition of $N$. oleoabundans grown in nitrogen deplete and replete conditions
Fatty acid composition

\begin{tabular}{|c|c|c|c|}
\hline Fatty acids & N-Replete & N-Deplete & References \\
\hline $\begin{array}{l}\text { C14:0 } \\
\text { (Breuer et al., 2012) }\end{array}$ & trace & 18 & (Garibay-Hernández et al., 2013); \\
\hline $\begin{array}{l}\text { C16:0 } \\
\text { (Sun et al., 2014); } \\
\text { (Garibay-Hernández et al., 2013); } \\
\text { (Santos et al., 2013); } \\
\text { (Breuer et al., 2012) }\end{array}$ & $24-31$ & $2-24$ & (Morales-Sánchez et al., 2014); \\
\hline $\begin{array}{l}\text { C16:1 } \\
\text { (Sun et al., 2014); } \\
\text { (Garibay-Hernández et al., 2013); } \\
\text { (Santos et al., 2013); } \\
\text { (Breuer et al., 2012) }\end{array}$ & $1-3$ & 4 & (Morales-Sánchez et al., 2014); \\
\hline $\begin{array}{l}\text { C16:2 } \\
\text { (Sun et al., 2014); } \\
\text { (Breuer et al., 2012) }\end{array}$ & $2-6$ & 6 & (Morales-Sánchez et al., 2014); \\
\hline $\begin{array}{l}\text { C16:3 } \\
\text { (Breuer et al., 2012) }\end{array}$ & 12 & 5 & (Sun et al., 2014); \\
\hline $\begin{array}{l}\text { C17:1 } \\
\text { (Garibay-Hernández et al., 2013) }\end{array}$ & $2-3$ & $1-2$ & Morales-Sánchez et al., 2014; \\
\hline $\begin{array}{l}\text { C18:0 } \\
\text { (Garibay-Hernández et al., 2013); } \\
\text { (Santos et al., 2013); } \\
\text { (Breuer et al., 2012) }\end{array}$ & $1-11$ & $3-11$ & (Sun et al., 2014); \\
\hline $\begin{array}{l}\text { C18:1 } \\
\text { (Sun et al., 2014); } \\
\text { (Garibay-Hernández et al., 2013); } \\
\text { (Santos et al., 2013); } \\
\text { (Breuer et al., 2012) }\end{array}$ & $8-54$ & $15-47$ & (Morales-Sánchez et al., 2014); \\
\hline $\begin{array}{l}\text { C18:2 } \\
\text { (Sun et al., 2014); } \\
\text { (Garibay-Hernández et al., 2013); } \\
\text { (Santos et al., 2013); } \\
\text { (Breuer et al., 2012) }\end{array}$ & $17-30$ & $16-26$ & (Morales-Sánchez et al., 2014); \\
\hline $\begin{array}{l}\text { C18:3n3 } \\
\text { (Garibay-Hernández et al., 2013); } \\
\text { (Santos et al., 2013); } \\
\text { (Breuer et al., 2012) }\end{array}$ & $3-4$ & $3-16$ & (Sun et al., 2014); \\
\hline
\end{tabular}

nitrogen sufficient and limited cultivation conditions (de Winter et al. 2013, 2014; Krzemińska et al. 2014;). The supply of electrons for the biomass growth and lipid synthesis can be controlled by the level of oxygen concentration in the gas phase in contact with the medium. Sousa et al., (2012) showed that an increase of the oxygen partial pressure from 0.24 up to 0.84 bar induced a $25 \%$ reduction of the growth rate (Sousa et al. 2013a). However, the study also showed that a parallel increase of the $\mathrm{CO}_{2}$ partial pressure can mitigate this effect, provided to operate the photobioreactor at sub-saturating light intensity (Sousa et al. 
2013a), while at saturating light intensity the inhibitory effect of oxygen by photorespiration cannot be overcome (Sousa et al. 2013a, b).

While the interest for lipid production is expected, in view of the lipid-accumulator feature of Neochloris, some other interesting applications of Neochloris strain have also been reported in literature. The superior efficacy of mixotrophic or even fully heterotrophic cultivation conditions (Giovanardi et al. 2013; Baldisserotto et al. 2016; Silva et al. 2016) has triggered the application of $N$. oleoabundans for waste treatment and valorisation. Neochloris biomass has been successfully cultivated on chicken manure (Altunoz et al. 2017), sewage sludge (Jeong et al. 2017), secondary wastewater from urban plants (Aravantinou et al. 2013), apple vinegar (Giovanardi et al. 2013), pig manure (Olguín et al. 2015a), vinasse digestate (Olguín et al. 2015b), pharmaceutical effluent (Singh et al. 2020), swine wastewater (Wang et al. 2017), biogas slurry (Zhao et al. 2015) and general municipal waste (Valev et al. 2020).

\section{6. Downstream processing}

\subsection{Cell disruption}

The cell wall rigidity of $N$. oleoabundans renders hard the extraction of the intracellular components. Hence, a unit operation of cell disruption is required to either weaken the integrity of the cell wall or to completely disrupt it to release the target components. Several cell disruption methods have been already tested on $N$. oleoabundans grown under different growth conditions (Safi et al. 2020), and showed a rather mitigated rate of success in terms of cell disruption effectiveness and release of components. The cell disruption methods consist of mechanical, enzymatic and chemical treatments.

\subsubsection{Pulsed electric field}

The method consists of creating pores on the cell membrane after applying intermittent electric field strength within a short period of time to release the intracellular components (Luengo et al. 2014). This method has been used to deactivate microbes in food products (juice, milk), to break the cell wall of yeast, as medical treatment such as electro-chemotherapy, and for genetic transformation. Hence, given that Pulsed Electric Field (PEF) showed promising results in terms of cell disruption of microorganisms with minimal energy input. Therefore, it has been considered as a promising technique to break the cell wall of microalgae. In the case of $N$. oleoabundans, cell wall disruption efficacy by PEF was not as successful as expected. According to a study (Lam et al. 2017), PEF was efficient to perforate the cell wall of $N$. oleoabundans to release ions. However, the perforation was not efficient enough to release larger molecules such as soluble proteins even when significantly increasing the energy input. This poor efficacy corresponds to the outcomes obtained when testing PEF on other rigid cell walled species such as Chlorella vulgaris (Lam et al. 2017) and Nannochloropsis gaditana (Safi et al. 2017) where 3 to $10 \%$ proteins (w/w) were released, respectively. Nonetheless, the poor efficacy of PEF to break the cell wall and release intracellular components of rigid cell walled microalgae does not necessarily imply that PEF will not be efficient on weak cell walled species (Safi et al. 2017). For instance, by means of PEF, highly pure $\beta$-Pycoerythrin and C-Phycocyanin were successfully extracted from Porphyridium cruentum and Arthrospira platensis, respectively (Martínez et al. 2019; Akaberi et al. 2020).

\subsubsection{Bead milling}

The mechanism of this method consists of an agitator and a milling chamber. The slurry is first filled in a vessel connected to an agitator in order to keep a proper dispersion of the microalgal cells. Subsequently, the slurry is pumped into the milling chamber that contains the beads, which mechanically disrupt the microalgal cells by means of friction between the beads and the cells. The method is considered as highly efficient in terms of cell disintegration and release of intracellular molecules. Indeed, similar to bead milling, a cooling system is integrated to the machine in order to avoid overheating the solution and the denaturation of target components.

Bead milling is one of the most efficient cell disruption methods that inflicts severe damage to the integrity of rigid cell walled microalgae. It has been reported that $>99 \%$ disintegration was reached after applying bead milling on $N$. oleoabundans with a specific energy input of $<0.5 \mathrm{kWh} . \mathrm{kg}^{-1}$ (Postma et al. 
2017). Nonetheless, the yield of soluble proteins released in the supernatant after bead milling (using 0.3 to $0.4 \mathrm{~mm}$ Yttrium stabilised $\mathrm{ZrO}_{2}$ beads) was 50 $\%$ (Lam et al. 2017) to $59 \%$ (Postma et al. 2017), and $68 \%$ carbohydrates (Postma et al. 2017). The study also concluded that a selective protein extraction occurred during the first 10 minutes of bead milling (Postma et al. 2017).

Another study assessed the effectiveness of bead milling on $N$. oleoabundans grown under nitrogen replete (NR) and deplete (ND) conditions (Gürenken et al. 2016). The study reached $100 \%$ cell wall disintegration, but the release of components differed between the cultivation conditions applied. Thereby, the release of proteins, carbohydrates and lipids for NR was $35 \%, 33 \%, 33 \%$, respectively. Whereas for ND the release of proteins, carbohydrates and lipids was $58 \%, 65 \%, 57 \%$, respectively.

\subsection{High pressure homogenization}

This method is commonly used to create emulsions, but also for cell disruption. It consists of forcing a solution through a system (shear forces, impact, cavitation) in order to homogenize it or reduce the particles size within the solution, thereby breaking the cell wall of microalgae. Indeed, similar to bead milling, a cooling system is integrated to the machine in order to avoid overheating the solution and the denaturation of target components.

High-pressure homogenization (HPH) was applied on several microalgae (Jubeau et al. 2012; Spiden et al. 2013; Safi et al. 2014; Yap et al. 2015; Safi et al. 2017) and showed high efficacy in terms of cell wall disintegration and release of intracellular components. With regards to $N$. oleoabundans grown under nitrogen replete condition, the disintegration rate was up to $>95 \%$ (Karthikeyan and Prathima 2017), and yielded $69 \%$ lipids (Wang et al. 2015) and $40 \%$ proteins (Safi et al. 2020). Nevertheless, the disintegration rate and the effectiveness of releasing intracellular components are directly correlated to the growth conditions that affect the composition and the rigidity of the cell wall of microalgae (Yap et al. 2016; Jeong et al. 2017; Rashidi et al. 2019; Safi et al. 2020).

\subsection{4 ltrasonication}

This method works by applying sound energy to produce cavitation on the cell wall, which facilitates the access to the intracellular components. Ultrasonication has shown mitigated results in terms of efficacy to break the cell wall of microalgae (Safi et al. 2014). For instance, this method was not efficient enough the break the cell wall and release the soluble proteins of green species like Chlorella vulgaris, Nannochloropsis oculata and Haematococcus pluvialis. Nevertheless, ultrasonication was more efficient on weak cell walled microalgae like Arthrospira platensis and Porphyridium cruentum (Safi et al. 2014). Although $N$. oleoabundans has a resistant cell wall, the microscopic observations showed that the cells were disintegrated (Karthikeyan and Prathima 2017) after applying ultrasonication, and the yield of lipids released was $53 \%(\mathrm{w} / \mathrm{w})$ (Wang et al. 2015).

\subsubsection{Enzymatic treatment}

The cell wall of $N$. oleoabundans contains proteins, cellulose and other components. This suggests that the choice of enzymes is an important factor given that the enzymatic approach focuses on hydrolysing one or several cell wall components to weaken the integrity of the cell wall, and have access to the intracellular molecules. SEM imaging showed intact cells after applying enzymatic treatment (Karthikeyan and Prathima 2017) on N. oleoabundans. This suggests that the enzymatic treatment softly disintegrates the cell wall but does not disintegrate the cell membrane, which results in the formation of fragile cell-like shaped protoplasts (Wang et al. 2015). Thus, by simply stirring the solution, the protoplasts will be easily disintegrated (Karthikeyan and Prathima 2017), and the intracellular soluble components will be released.

The enzymatic approach was also applied by combining multiple enzymes (cellulase and papain) in order to extract lipids from $N$. oleoabundans (Wang et al. 2015). The disintegration efficacy was not as high as bead milling, and the release of lipids was $46 \%$ (w/w). Furthermore, the study also considered combining the enzymatic treatment with high-pressure homogenization or ultrasonication (Wang et al. 2015). Both combinations led to a high disintegration rate, and a higher release of lipids up to $93 \%$ and $76 \%$ (w/ 
w), respectively. This implies that combining two cell disruption methods is a plausible approach as long as the overall cost of the operation remains acceptable.

\subsection{Fractionation}

\subsubsection{Ionic liquids (IL) and aqueous two-phase system (ATPS)}

ATPS is a liquid-liquid extraction method that is based on employing two immiscible aqueous solutions to separate components (Yau et al. 2015). According to Asenjo and Andrews (2011) ATPS exploits the incompatibility between aqueous solutions of two polymers, or a polymer and a salt at high ionic strength. Hence, as the polymers are mixed, large aggregates form and the two polymers will tend to separate into two different phases due to steric exclusion (Asenjo and Andrews 2011). Moreover, ATPS is described as an efficient, scalable and mild technique that preserves the functional integrity of the extracted molecules (Rosa et al. 2011) such as proteins and pigments. Therefore, the extraction of proteins by means of ATPS (Iolilyte 221PG - citrate system or PEG 400 - potassium citrate system) showed that $N$. oleoabundans proteins migrate efficiently to the upper phase (80 to $100 \%$ extraction efficacy) during phase separation (Figure 1). It has been implied that proteins favour the upper phase during the partitioning process due to their net charge and not their molecular weight (Suarez Garcia et al. 2018). On the other hand, the high affinity of sugars to water and their lack of charge triggered their migration to the bottom phase (>90\% extraction efficacy), thereby inducing an efficient separation from proteins (Suarez Garcia et al., 2018). Moreover, ATPS can take multiple forms based on the target components that require separation. For instance, Suarez-Ruiz et al. (2018) separated pigments (chlorophyll and lutein) from proteins by using a polymer (PEG 400) and an ionic liquid (Ch Dhp). However, in this case, pigments migrated to the upper polymer phase with an extraction efficacy of $97 \%$ and $52 \%$ for lutein and chlorophyll, respectively, whereas proteins were detected in the interface with an extraction e of $92 \%$ (Suarez Ruiz et al. 2018). Furthermore, Suarez-Ruiz et al. (2020b) fractionated pigments, carbohydrates, proteins and lipids by means of ATPS followed by a purification process using ultrafiltration (10 $\mathrm{kDa}$ regenerated cellulose membrane) (Suarez Ruiz et al. 2020). Desai et al. (2019) separated the hydrophobic fraction from the hydrophilic fraction by using the ionic liquid tributylmethylphosphonium methylsulfate $\left(\mathrm{TBP} \mathrm{SO}_{4}\right)$. The study concluded that TBP SO4 was able to permeabilise the cell wall of fresh intact cells of $N$. oleoabundans to release $68 \%$ of total lipids (Desai et al. 2019). Subsequently, the hydrophilic fraction (proteins and carbohydrates) was further extracted in an aqueous buffer after applying bead milling.

\subsubsection{Membrane filtration}

Further fractionation or purification of the crude extracts without employing toxic chemicals could be achieved by filtration. The unit operation consists of passing the solution through a filter on which some components will be retained based on their molecular weight. Multiple parameters should be taken into
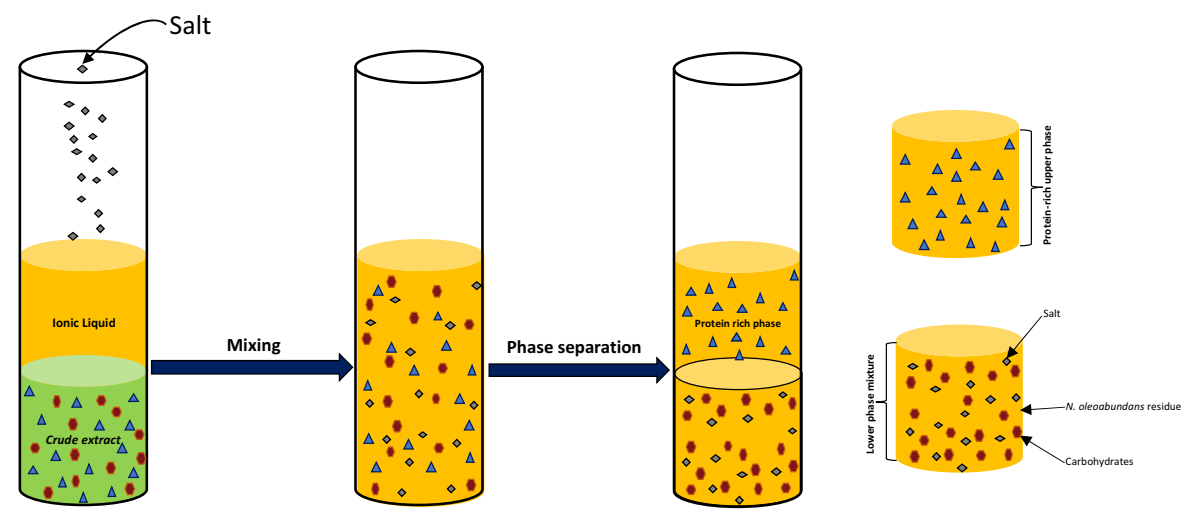

Fig. 1 Schematic example of an aqueous two-phase system to separate proteins from carbohydrates by means of ionic liquids and salts 


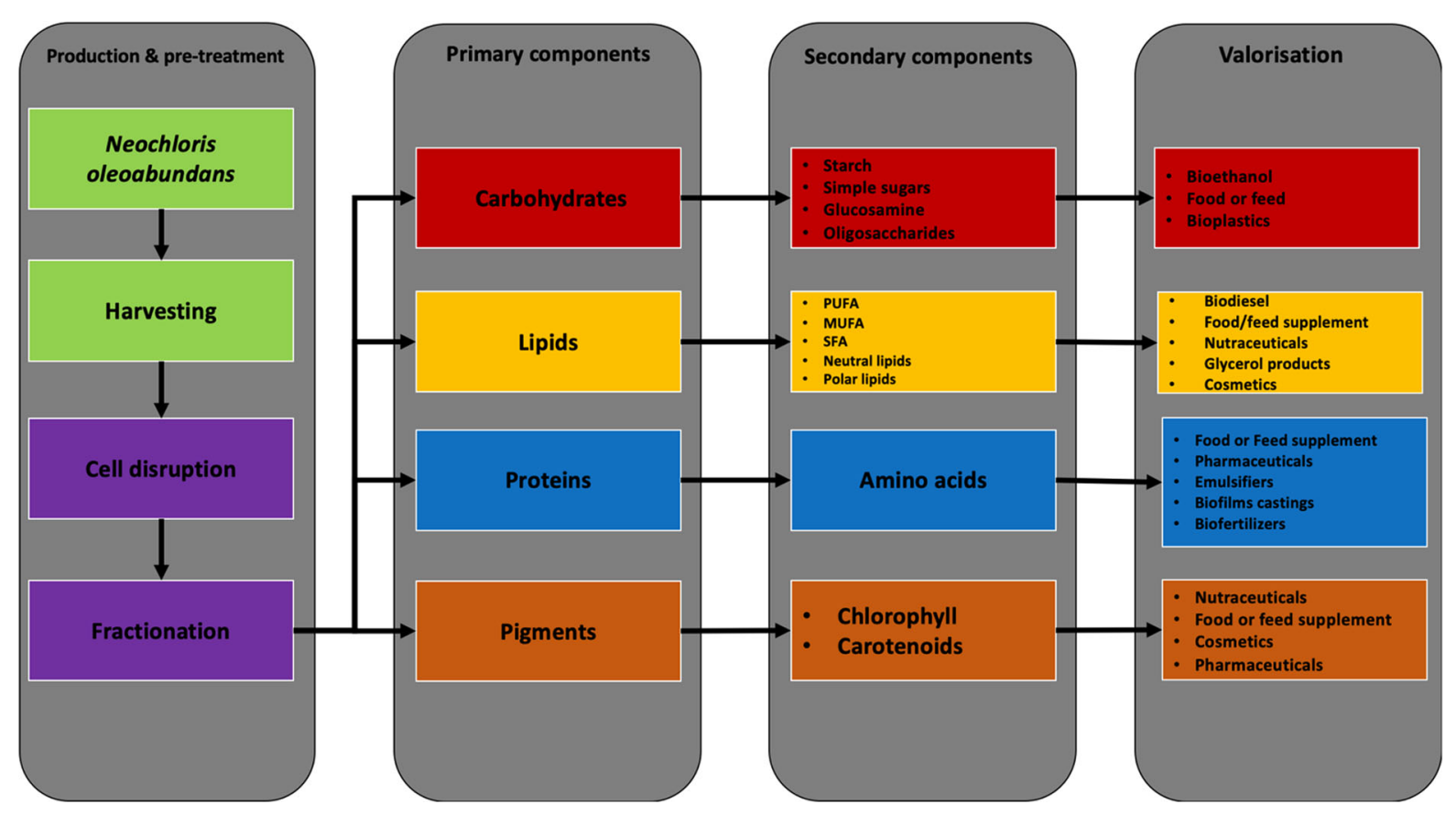

Fig. 2 Schematic description of the value chain of N. oleoabundans

consideration while operating this unit operation such as filter composition, transmembrane pressure, cut-off of the membrane and flow velocity, turbulent crossflow. Therefore, a correct combination of parameters is always required to properly operate a filtration unit and limit the fouling phenomenon. In downstream processing of microalgae, filtration is used to either concentrate or to purify a target component obtained from the crude extract. Suarez Ruiz et al. (2020a) recovered $96 \%$ of the ionic liquid in the permeate, and retained $82 \%$ of the proteins obtained from the crude extract after ionic liquids extraction by using a $10 \mathrm{kDa}$ polyethersulfone membrane (Suarez Ruiz et al. 2020a). Indeed, the literature on filtration of $N$. oleoabundans molecules is poor, but many studies applied this specific unit operation on other microalgal species, and therefore it can be extrapolated to $N$. oleoabundans. For instance, ultrafiltration was carried out to purify polysaccharides from Porphyridium cruentum (Patel et al. 2013; Macarti et al. 2014), Spirulina platensis and Chlorella pyrenoidosa (Pugh et al. 2001), or to concentrate proteins from Chlorella vulgaris and Haematococcus pluvialis in the retentate (Ursu et al. 2014; Ba et al. 2016). Other studies adopted a different approach when purifying the components of on Tetraselmis suecica and
Nannochloropsis gaditana (Safi et al. 2014; Safi et al. 2017) by obtaining the proteins in the filtrate instead of the retentate.

\section{Valorisation track}

$N$. oleoabundans gathers many features that make it an excellent candidate for a full valorisation. Basically, this species attracted attention for its capacity to accumulate lipids suitable for biodiesel production, to grow in marine and fresh water, and to clean wastewater. Nevertheless, looking at all the highvalue components present in $N$. oleoabundans (Fig. 2), it would be more reasonable to valorise the remaining components (proteins, PUFAs, carbohydrates and pigments), which will increase profitability, promote the concept of circularity and most importantly, it is more sustainable. The complete valorisation approach has been previously studied (Wijffels et al. 2010) and showed that with a wider biomass valorisation, the process can significantly increase the profit compared to simply valorising it for biodiesel. Therefore, by employing a proper combination of unit operations, and by valorising the valuable components, the value of the microalgal biomass has the 
potential to reach $\pm 1600 € /$ ton after a complete valorisation (Wijffels et al. 2010).

Figure 2 represents the potential economic exploitation of $N$. oleoabundans. Starting from large scale production, the fractionation in the main component classes (lipids, carbohydrates and proteins) is followed by the purification in sub-fractions (soluble and insoluble proteins, starch, polar and neutral lipids), and the possible chemical conversion of some of them into other added values (protein hydrolysis into amino-acids, lipids esterification in fatty acids methyl-esters). All these fractions might be addressed to different markets, provided a product validation is performed at a demonstrative scale.

Currently, the status of any Neochloris-based value chain is at TRL not larger than 5 and few proofs of purification of secondary components are reported at that level. Indeed, despite the versatility in production conditions and in accumulation of either lipids or protein rich fractions, only few projects focused their efforts on Neochloris (Fuel4Me, AlgaePARC Biorefinery, Greenbiorefinery). Thus, it would be advisable that future projects take into consideration Neochloris in order to properly exploit it and valorise its valuable components.

\section{Conclusion}

$N$. oleoabundans has the capacity to grow efficiently in saline, fresh and wastewater. It accumulates valuable components that can be fractionated by employing multiple unit operations. The ratio of these components can vary based on the growth conditions. Although N. oleoabundans has a resistant cell wall, the growth conditions applied affect its cell wall physiology, making it less or more resistant to cell disruption. Moreover, the value chain scheme showed all the possible valorisation paths that lead to the development of end-products.

Acknowledgements The authors would like to thank Dr. Ben van den Broek and Dr. Lolke Sijtsma for their valuable advice throughout the writing process of the review. This research did not receive any specific grant from funding agencies in the public, commercial, or not-for-profit sectors.

Funding The authors declare the following financial interests/ personal relationships which may be considered as potential competing interests.

\section{Declarations}

Conflict of interests The authors declare that they have no known competing financial interests or personal relationships that could have appeared to influence the work reported in this paper.

Open Access This article is licensed under a Creative Commons Attribution 4.0 International License, which permits use, sharing, adaptation, distribution and reproduction in any medium or format, as long as you give appropriate credit to the original author(s) and the source, provide a link to the Creative Commons licence, and indicate if changes were made. The images or other third party material in this article are included in the article's Creative Commons licence, unless indicated otherwise in a credit line to the material. If material is not included in the article's Creative Commons licence and your intended use is not permitted by statutory regulation or exceeds the permitted use, you will need to obtain permission directly from the copyright holder. To view a copy of this licence, visit http://creativecommons.org/licenses/by/4.0/.

\section{References}

Akaberi S, Krust D, Müller G et al (2020) Impact of incubation conditions on protein and C-Phycocyanin recovery from Arthrospira platensis post- pulsed electric field treatment. Bioresour Technol 306:123099. https://doi.org/10.1016/j. biortech.2020.123099

Altunoz M, Pirrotta O, Forti L et al (2017) Combined effects of LED lights and chicken manure on Neochloris oleoabundans growth. Bioresour Technol 244:1261-1268. https:// doi.org/10.1016/j.biortech.2017.04.094

Altunoz M, Allesina G, Pedrazzi S et al (2020) Integration of biological waste conversion and wastewater treatment plants by microalgae cultivation. Process Biochem 91:158-164. https://doi.org/10.1016/j.procbio.2019.12. 007

Aravantinou AF, Theodorakopoulos MA, Manariotis ID (2013) Selection of microalgae for wastewater treatment and potential lipids production. Bioresour Technol 147:130-134. https://doi.org/10.1016/j.biortech.2013.08. 024

Arce G, Bold HC (1958) Some chlorophyceae from cuban soils. Am J Bot 45:492-503. https://doi.org/10.2307/2439186

Archibald PA (1973) The genus neochloris starr (chlorophyceae, chlorococcales). Phycologia 12:187-193. https:// doi.org/10.2216/i0031-8884-12-3-187.1

Asenjo JA, Andrews BA (2011) Aqueous two-phase systems for protein separation: a perspective. J Chromatogr A 1218:8826-8835. https://doi.org/10.1016/j.chroma.2011. 06.051

Avagyan AB (2010) New design and build biological system addressed to global environment management and sustainable development through including microalgae and their biomass in production and bio cycles. J Environ Prot 1:183-200. https://doi.org/10.4236/jep.2010.12023

Avagyan AB (2013) Theory of global sustainable development based on microalgae in bio and industrial cycles, 
management-changing decisions in areas of climate change and waste management. J Sustain Bioenergy Syst 3:287-297. https://doi.org/10.4236/jsbs.2013.34038

Avagyan AB (2021) Theory of bioenergy accumulation and transformation: application to evolution, energy, sustainable development, climate change, manufacturing, agriculture, military activity and pandemic challenges. Athens J Sci 8:57-80. https://doi.org/10.30958/ajs.8-1-4

Avagyan AB, Singh B (2019) Biodiesel: feedstocks, technologies, economics and barriers. Assess Environ Impact Prod Using Chains 23:137. https://doi.org/10.1007/978-981-135746-6

Avagyan AB (2018) Algae to energy and sustainable development. $1^{\text {st }}$ Edition,ISBN-10: 1718722559

Ba F, Ursu AV, Laroche C et al (2016) Haematococcus pluvialis soluble proteins: Extraction, characterization, concentration/fractionation and emulsifying properties. Bioresour Technol 200:147-152. https://doi.org/10.1016/j.biortech. 2015.10.012

Baldisserotto C, Ferroni L, Giovanardi M et al (2012) Salinity promotes growth of freshwater Neochloris oleoabundans UTEX 1185 (Sphaeropleales, Chlorophyta): morphophysiological aspects. Phycologia 53:700-710. https://doi.org/ 10.2216/11-099.1

Baldisserotto C, Giovanardi M, Ferroni L et al (2014) Growth, morphology and photosynthetic responses of Neochloris oleoabundans during cultivation in a mixotrophic brackish medium and subsequent starvation. Acta Physiol Plant 36:461-472. https://doi.org/10.1007/s11738-013-1426-3

Baldisserotto C, Popovich C, Giovanardi M et al (2016) Photosynthetic aspects and lipid profiles in the mixotrophic alga Neochloris oleoabundans as useful parameters for biodiesel production. Algal Res 16:255-265. https://doi. org/10.1016/j.algal.2016.03.022

Banerjee S, Singh H, Das D et al (2019) Process optimization for enhanced biodiesel production by neochloris oleoabundans UTEX 1185 with concomitant CO2 sequestration. Ind Eng Chem Res 58:15760-15771. https://doi.org/10.1021/acs. iecr. 8 b05730

Barsanti L, Gualtieri P (2010) Algae : anatomy, biochemistry, and biotechnology. Second edition

Bertuzzi S, Gustavs L, Pandolfini G et al (2017) Heat shock treatments for the control of lithobionts: a case study with epilithic green microalgae. Int Biodeter Biodegr 123:236-243. https://doi.org/10.1016/j.ibiod.2017.06.023

Billi D, Potts M (2000) Life without water: responses of prokaryotes to desiccation. Biology Chapter 13:181-192. https://doi.org/10.1016/S1568-1254(00)80015-7

Bold HC (1958) Three new chlorophycean alga. Am J Bot 45:737-743. https://doi.org/10.2307/2439733

Bona F, Capuzzo A, Franchino M et al (2014) Semicontinuous nitrogen limitation as convenient operation strategy to maximize fatty acid production in Neochloris oleoabundans. Algal Res 5:1-6. https://doi.org/10.1016/j.algal. 2014.03.007

Breuer G, Lamers PP, Martens DE et al (2012) The impact of nitrogen starvation on the dynamics of triacylglycerol accumulation in nine microalgae strains. Bioresour Technol 124:217-226. https://doi.org/10.1016/j.biortech.2012. 08.003
Castro-Puyana M, Herrero M, Urreta I et al (2013) Optimization of clean extraction methods to isolate carotenoids from the microalga Neochloris oleoabundans and subsequent chemical characterization using liquid chromatography tandem mass spectrometry. Anal Bioanal Chem 405:4607-4616. https://doi.org/10.1007/s00216-012$6687-y$

Chantanachat S, Bold HC (1962) Some algae from arid soils. Texas University

Chapman RL, Waters DA (2002) Green Algae and Land Plants-An Answer At Last? J Phycol 38:237-240

Chungjatupornchai W, Areerat K, Fa-Aroonsawat S (2019) Increased triacylglycerol production in oleaginous microalga Neochloris oleoabundans by overexpression of plastidial lysophosphatidic acid acyltransferase. Microb Cell Fact 18:53. https://doi.org/10.1186/s12934-019-1104-2

Courchesne NMD, Parisien A, Wang B et al (2009) Enhancement of lipid production using biochemical, genetic and transcription factor engineering approaches. J Biotechnol 141:31-41. https://doi.org/10.1016/j.jbiotec.2009.02.018

de Jaeger L, Carreres BM, Springer J et al (2018) Neochloris oleoabundans is worth its salt: transcriptomic analysis under salt and nitrogen stress. PLoS ONE. https://doi.org/ 10.1371/journal.pone.0194834

de Winter L, Klok AJ, Cuaresma Franco M et al (2013) The synchronized cell cycle of Neochloris oleoabundans and its influence on biomass composition under constant light conditions. Algal Res 2:313-320. https://doi.org/10.1016/j. algal.2013.09.001

de Winter L, Schepers LW, Cuaresma M et al (2014) Circadian rhythms in the cell cycle and biomass composition of Neochloris oleoabundans under nitrogen limitation. J Biotechnol 187:25-33. https://doi.org/10.1016/j.jbiotec. 2014.07.016

de Winter L, Cabanelas ITD, Martens DE et al (2017) The influence of day/night cycles on biomass yield and composition of Neochloris oleoabundans. Biotechnol Biofuels 10:104. https://doi.org/10.1186/s13068-017-0762-8

de Winter L, Cabanelas ITD, Órão AN et al (2017) The influence of day length on circadian rhythms of Neochloris oleoabundans. Algal Res 22(31):38. https://doi.org/10. 1016/j.algal.2016.12.001

Deason TR, Silva PC, Watanabe S et al (1991) Taxonomic status of the species of the green algal genus Neochloris. Plant Sust Evol 177:213-219. https://doi.org/10.1007/ BF00937958

Desai RK, Fernandez MS, Wijffels RH et al (2019) Mild fractionation of hydrophilic and hydrophobic components from neochloris oleoabundans using ionic liquids. Front Bioeng Biotechnol 7:284. https://doi.org/10.3389/fbioe.2019. 00284

Garibay-Hernández A, Vazquez-Duhalt R, Serrano-Carreón L et al (2013) Nitrogen limitation in neochloris oleoabundans: a reassessment of its effect on cell growth and biochemical composition. Appl Biochem Biotech 171:1775-1791. https://doi.org/10.1007/s12010-0130454-1

Giovanardi M, Ferroni L, Baldisserotto C et al (2013) (2013) Morphophysiological analyses of Neochloris oleoabundans (Chlorophyta) grown mixotrophically in a carbon-rich 
waste product. Protoplasma 250:161-174. https://doi.org/ 10.1007/s00709-012-0390-x

Gouveia L, Marques A, da Silva T et al (2009) Neochloris oleabundans UTEX \#1185: a suitable renewable lipid source for biofuel production. $\mathrm{J}$ Ind Microbiol Biot 36:821-826. https://doi.org/10.1007/s10295-009-0559-2

Gray DW, Lewis LA, Cardon ZG (2007) Photosynthetic recovery following desiccation of desert green algae (Chlorophyta) and their aquatic relatives. Plant Cell Environ 30:1240-1255. https://doi.org/10.1111/j.13653040.2007.01704.x

Günerken E, D'Hondt E, Eppink M et al (2016) Influence of nitrogen depletion in the growth of $\mathrm{N}$. oleoabundans on the release of cellular components after beadmilling. Bioresour Technol 214:89-95. https://doi.org/10.1016/j.biortech. 2016.04.072

Gustavs L, Eggert A, Michalik D et al (2010) Physiological and biochemical responses of green microalgae from different habitats to osmotic and matric stress. Protoplasma 243:3-14. https://doi.org/10.1007/s00709-009-0060-9

Henschel JR, Seely MK (2008) Ecophysiology of atmospheric moisture in the Namib Desert. Atmos Res 87:362-368. https://doi.org/10.1016/j.atmosres.2007.11.015

Herndon W (1958) Some new species of chlorosphaerean algae from soil. Am J Bot 45:308-323

Jazzar S, Berrejeb N, Messaoud C et al (2016) Growth parameters, photosynthetic performance, and biochemical characterization of newly isolated green microalgae in response to culture condition variations. Appl Biochem Biotech 179:1290-1308. https://doi.org/10.1007/s12010-0162066-Z

Jeong SW, Nam SW, HwangBo K et al (2017) Transcriptional regulation of cellulose biosynthesis during the early phase of nitrogen deprivation in nannochloropsis salina. Sci RepUK 7:5264. https://doi.org/10.1038/s41598-017-05684-4

Jubeau S, Marchal L, Pruvost J et al (2012) High pressure disruption: a two-step treatment for selective extraction of intracellular components from the microalga Porphyridium cruentum. J Appl Phycol 25:983-989. https://doi.org/10. 1007/s10811-012-9910-5

Karthikeyan S, Prathima A (2017) Neochloris oleoabundans microalgae oil as a fuel for diesel engines. Energ Source Part A 39:606-612. https://doi.org/10.1080/15567036. 2016.1248800

Klok AJ, Martens DE, Wijffels RH et al (2013a) Simultaneous growth and neutral lipid accumulation in microalgae. Bioresour Technol 134:233-243. https://doi.org/10.1016/j. biortech.2013.02.006

Klok AJ, Verbaanderd JA, Lamers PP et al (2013b) A model for customising biomass composition in continuous microalgae production. Bioresour Technol 146:89-100. https:// doi.org/10.1016/j.biortech.2013.07.039

Komárek R (1989) Polynuclearity of vegetative cells in coccal green algae from the family neochloridaceae. Arch Protistenkd 137:255-273. https://doi.org/10.1016/S00039365(89)80033-8

Krzemińska I, Pawlik-Skowrońska B, Trzcińska M et al (2014) Influence of photoperiods on the growth rate and biomass productivity of green microalgae. Bioprocess Biosyst Eng 37:735-741. https://doi.org/10.1007/s00449-013-1044-x
Kwak HS, Kim JYH, Sim SJ (2015) A microscale approach for simple and rapid monitoring of cell growth and lipid accumulation in Neochloris oleoabundans. Bioproc Biosyst Eng 38:2035-2043. https://doi.org/10.1007/s00449015-1444-1

Lam GP, Postma PR, Fernandes DA et al (2017) Pulsed electric Field for protein release of the microalgae Chlorella vulgaris and Neochloris oleoabundans. Algal Res 24(181):187. https://doi.org/10.1016/j.algal.2017.03.024

Li Y, Horsman M, Wang B et al (2008) Effects of nitrogen sources on cell growth and lipid accumulation of green alga Neochloris oleoabundans. Appl Microbiol Biot 81:629-636. https://doi.org/10.1007/s00253-008-1681-1

Luengo E, Condón-Abanto S, Álvarez I et al (2014) Effect of pulsed electric field treatments on permeabilization and extraction of pigments from chlorella vulgaris. J Membrane Biol 247:1269-1277. https://doi.org/10.1007/ s00232-014-9688-2

Mail CD. (2001) All land plants evolved from single type of algae, Scientists say charleston daily mail.

Mandal S, Mallick N (2009) Microalga Scenedesmus obliquus as a potential source for biodiesel production. Appl Microbiol Biot 84:281-291. https://doi.org/10.1007/ s00253-009-1935-6

Marcati A, Ursu AV, Laroche C et al (2014) Extraction and fractionation of polysaccharides and B-phycoerythrin from the microalga Porphyridium cruentum by membrane technology. Algal Res 5:258-263. https://doi.org/10.1016/ j.algal.2014.03.006

Martínez JM, Delso C, Álvarez I et al (2019) Pulsed electric field permeabilization and extraction of phycoerythrin from Porphyridium cruentum. Algal Res 37:51-56. https://doi. org/10.1016/j.algal.2018.11.005

Morales-Sánchez D, Tinoco-Valencia R, Kyndt J et al (2013) Heterotrophic growth of Neochloris oleoabundans using glucose as a carbon source. Biotechnol Biofuels 6:1-13. https://doi.org/10.1186/1754-6834-6-100

Morales-Sánchez D, Tinoco-Valencia R, Caro-Bermúdez MA et al (2014) Culturing Neochloris oleoabundans microalga in a nitrogen-limited, heterotrophic fed-batch system to enhance lipid and carbohydrate accumulation. Algal Res 5:61-69. https://doi.org/10.1016/j.algal.2014.05.006

Murray K, Healy F, McCord R et al (2011) Biomass production and nutrient uptake by Neochloris oleoabundans in an open trough system. Appl Microbiol Biot 90:89-95. https://doi. org/10.1007/s00253-010-3054-9

Olguín EJ, Castillo OS, Mendoza A et al (2015a) Dual purpose system that treats anaerobic effluents from pig waste and produce Neochloris oleoabundans as lipid rich biomass. New Biotechnol 32:387-395. https://doi.org/10.1016/j.nbt. 2014.12.004

Olguín EJ, Dorantes E, Castillo OS et al (2015b) Anaerobic digestates from vinasse promote growth and lipid enrichment in Neochloris oleoabundans cultures. J Appl Phycol 27:1813-1822. https://doi.org/10.1007/s10811-015-05406

Patel AK, Laroche C, Marcati A et al (2013) Separation and fractionation of exopolysaccharides from Porphyridium cruentum. Bioresour Technol 145:345-350. https://doi. org/10.1016/j.biortech.2012.12.038 
Pegg C, Wolf M, La A et al (2015) Morphological diversity masks phylogenetic similarity of Ettlia and Haematococcus (Chlorophyceae). Phycologia 54:385-397. https://doi. org/10.2216/15-015.1

Peng L, Zhang Z, Lan CQ et al (2017) Alleviation of oxygen stress on Neochloris oleoabundans: effects of bicarbonate and pH. J Appl Phycol 29:143-152. https://doi.org/10. 1007/s10811-016-0931-3

Popovich CA, Damiani C, Constenla D et al (2012) Neochloris oleoabundans grown in enriched natural seawater for biodiesel feedstock: Evaluation of its growth and biochemical composition. Bioresour Technol 114:287-293. https://doi. org/10.1016/j.biortech.2012.02.121

Postma PR, Suarez-Garcia E, Safi C et al (2017) Energy efficient bead milling of microalgae: effect of bead size on disintegration and release of proteins and carbohydrates. Bioresour Technol 224:670-679. https://doi.org/10.1016/j. biortech.2016.11.071

Praveenkumar R, Shameera K, Mahalakshmi G et al (2012) Influence of nutrient deprivations on lipid accumulation in a dominant indigenous microalga Chlorella sp., BUM11008: evaluation for biodiesel production. Biomass Bioenerg 37:60-66. https://doi.org/10.1016/j.biombioe. 2011.12.035

Pruvost J, Van Vooren G, Cogne G et al (2009) Investigation of biomass and lipids production with Neochloris oleoabundans in photobioreactor. Bioresour Technol 100:5988-5995. https://doi.org/10.1016/j.biortech.2009. 06.004

Pugh N, Ross SA, ElSohly HN et al (2001) Isolation of three high molecular weight polysaccharide preparations with potent immunostimulatory activity from Spirulina platensis, aphanizomenon flos-aquae and Chlorella pyrenoidosa. Planta Med 67:737-742. https://doi.org/10.1055/s-200118358

Rashidi B, Trindade LM (2018) Detailed biochemical and morphologic characteristics of the green microalga Neochloris oleoabundans cell wall. Algal Res 35:152-159. https://doi.org/10.1016/j.algal.2018.08.033

Rashidi B, Dechesne A, Rydahl MG et al (2019) Neochloris oleoabundans cell walls have an altered composition when cultivated under different growing conditions. Algal Res 40:101482. https://doi.org/10.1016/j.algal.2019.101482

Rosa PAJ, Azevedo AM, Sommerfeld S et al (2011) Aqueous two-phase extraction as a platform in the biomanufacturing industry: economical and environmental sustainability. Biotechnol Adv 29:559-567. https://doi.org/10.1016/j. biotechadv.2011.03.006

Safi C, Zebib B, Merah O et al (2014a) Morphology, composition, production, processing and applications of Chlorella vulgaris: a review. Renew Sust Energ Rev 35:265-278. https://doi.org/10.1016/j.rser.2014.04.007

Safi C, Ursu AV, Laroche C et al (2014b) Aqueous extraction of proteins from microalgae: effect of different cell disruption methods. Algal Res 3:61-65. https://doi.org/10.1016/j. algal.2013.12.004

Safi C, Liu DZ, Yap BHJ et al (2014c) A two-stage ultrafiltration process for separating multiple components of Tetraselmis suecica after cell disruption. J Appl Phycol 26:2379-2387. https://doi.org/10.1007/s10811-014-0271-0
Safi C, Cabas Rodriguez L, Mulder WJ et al (2017a) Energy consumption and water-soluble protein release by cell wall disruption of Nannochloropsis gaditana. Bioresour Technol 239:204-210. https://doi.org/10.1016/j.biortech.2017. 05.012

Safi C, Olivieri G, Campos RP et al (2017b) Biorefinery of microalgal soluble proteins by sequential processing and membrane filtration. Bioresour Technol 225:151-158. https://doi.org/10.1016/j.biortech.2016.11.068

Safi C, Olivieri G, Engelen-Smit N et al (2020) Effect of growth conditions on the efficiency of cell disruption of Neochloris oleoabundans. Bioresour Technol 300:122699. https://doi. org/10.1016/j.biortech.2019.122699

Santos AM, Lamers PP, Janssen M et al (2013) Biomass and lipid productivity of Neochloris oleoabundans under alkaline-saline conditions. Algal Res 2:204-211. https:// doi.org/10.1016/j.algal.2013.04.007

Santos AM, Wijffels RH, Lamers PP (2014) pH-upshock yields more lipids in nitrogen-starved Neochloris oleoabundans. Bioresour Technol 152:299-306. https://doi.org/10.1016/j. biortech.2013.10.079

Sepulveda C, Gómez C, El Bahraoui N et al (2019) Comparative evaluation of microalgae strains for $\mathrm{CO} 2$ capture purposes. J CO2 Util 30:158-167. https://doi.org/10.1016/j.jcou. 2019.02.004

Silva HR, Prete CEC, Zambrano F et al (2016) Combining glucose and sodium acetate improves the growth of Neochloris oleoabundans under mixotrophic conditions. AMB Express 6:10. https://doi.org/10.1186/s13568-0160180-5

Sinetova MP, Markelova AG, Los DA (2006) The effect of nitrogen starvation on the ultrastructure and pigment composition of chloroplasts in the acidothermophilic microalga Galdieria sulphuraria. Russ J Plant Physl 53(2):153-162. https://doi.org/10.1134/ S1021443706020026

Singh A, Ummalyma SB, Sahoo D (2020) Bioremediation and biomass production of microalgae cultivation in river watercontaminated with pharmaceutical effluent. Bioresour Technol 307:123233. https://doi.org/10.1016/j. biortech.2020.123233

Sousa C, de Winter L, Janssen M et al (2012) Growth of the microalgae Neochloris oleoabundans at high partial oxygen pressures and sub-saturating light intensity. Bioresour Technol 104:565-570. https://doi.org/10.1016/j.biortech. 2011.10 .048

Sousa C, Compadre A, Vermuë MH et al (2013a) Effect of oxygen at low and high light intensities on the growth of Neochloris oleoabundans. Algal Res 2:122-126. https:// doi.org/10.1016/j.algal.2013.01.007

Sousa C, Valev D, Vermuë MH et al (2013b) Effect of dynamic oxygen concentrations on the growth of Neochloris oleoabundans at sub-saturating light conditions. Bioresour Technol 142:95-100. https://doi.org/10.1016/j.biortech. 2013.05.041

Spiden EM, Yap BHJ, Hill DRA et al (2013) Quantitative evaluation of the ease of rupture of industrially promising microalgae by high pressure homogenization. Bioresour Technol 140:165-171. https://doi.org/10.1016/j.biortech. 2013.04.074 
Starr RC (1957) A comparative study of Chlorococcum meneghini, and other spherical, zoospore-producing genera of the Chlorococcales. Q Rev Biol 32:4. https://doi.org/ 10.1086/402032

Suarez Garcia E, Suarez Ruiz CA, Tilaye T et al (2018) Fractionation of proteins and carbohydrates from crude microalgae extracts using an ionic liquid based-aqueous two phase system. Sep Purif Technol 204:56-65. https:// doi.org/10.1016/j.seppur.2018.04.043

Suarez Ruiz CA, Emmery DP, Wijffels RH et al (2018) Selective and mild fractionation of microalgal proteins and pigments using aqueous two-phase systems. J Chem Technol Biot 93:2774-2783. https://doi.org/10.1002/jctb. 5711

Suarez Ruiz CA, Kwaijtaal J, Peinado OC et al (2020a) Multistep fractionation of microalgal biomolecules using selective aqueous two-phase systems. Acs Sustain Chem Eng 8:2441-2452. https://doi.org/10.1021/acssuschemeng. 9b06379

Suarez Ruiz CA, Baca SZ, van den Broek LAM et al (2020b) Selective fractionation of free glucose and starch from microalgae using aqueous two-phase systems. Algal Res 46:101801. https://doi.org/10.1016/j.algal.2020.101801

Sun X, Cao Y, Xu H et al (2014) Effect of nitrogen-starvation, light intensity and iron on triacylglyceride/carbohydrate production and fatty acid profile of Neochloris oleoabundans HK-129 by a two-stage process. Bioresour Technol 155:204-212

Tibbetts SM, Milley JE, Lall SP (2015) Chemical composition and nutritional properties of freshwater and marine microalgal biomass cultured in photobioreactors. J Appl Phycol 27:1109-1119. https://doi.org/10.1007/s10811014-0428-x

Tornabene TG, Holzer G, Lien S et al (1983) Lipid composition of the nitrogen starved green alga Neochloris oleoabundans. Enzyme Microb Tech 5:435-440. https://doi.org/10. 1016/0141-0229(83)90026-1

Ursu AV, Marcati A, Sayd T et al (2014) Extraction, fractionation and functional properties of proteins from the microalgae Chlorella vulgaris. Bioresour Technol 157:134-139. https://doi.org/10.1016/j.biortech.2014.01. 071

Valev D, Silva Santos H, Tyystjärvi E (2020) Stable wastewater treatment with Neochloris oleoabundans in a tubular photobioreactor. J Appl Phycol 32:399-410. https://doi.org/10. 1007/s10811-019-01890-х

Villa JA, Ray EE, Barney BM (2014) Azotobacter vinelandii siderophore can provide nitrogen to support the culture of the green algae Neochloris oleoabundans and Scenedesmus sp. BA032. FEMS Microbiol Lett 351:70-77. https://doi. org/10.1111/1574-6968.12347
Wang B, Lan CQ (2011) Biomass production and nitrogen and phosphorus removal by the green alga Neochloris oleoabundans in simulated wastewater and secondary municipal wastewater effluent. Bioresour Technol 102:5639-5644. https://doi.org/10.1016/j.biortech.2011. 02.054

Wang D, Li Y, Hu X et al (2015) Combined enzymatic and mechanical cell disruption and lipid extraction of green alga neochloris oleoabundans. Int J Mol Sci 16:7707-7722. https://doi.org/10.3390/ijms16047707

Wang Y, Ho SH, Cheng CL et al (2017) Nutrients and COD removal of swine wastewater with an isolated microalgal strain Neochloris aquatica CL-M1 accumulating high carbohydrate content used for biobutanol production. Bioresour Technol 242:7-14. https://doi.org/10.1016/j.biortech. 2017.03.122

Watanabe S, Floyd GL (1989) Comparative ultrastructure of the zoospores of nine species ofNeochloris (Chlorophyta). Plant Syst Evol 168:195-219. https://doi.org/10.1007/ BF00936099

Wijffels RH, Barbosa MJ, Eppink MHM (2010) Microalgae for the production of bulk chemicals and biofuels. Biofuel Bioprod Bior 4:287-295. https://doi.org/10.1002/bbb.215

Yap BHJ, Dumsday GJ, Scales PJ et al (2015) Energy evaluation of algal cell disruption by high pressure homogenisation. Bioresour Technol 184:280-285. https://doi.org/10.1016/j. biortech.2014.11.049

Yap BHJ, Crawford SA, Dagastine RR et al (2016) Nitrogen deprivation of microalgae: effect on cell size, cell wall thickness, cell strength, and resistance to mechanical disruption. J Ind Microbiol Biot 43:1671-1680. https://doi. org/10.1007/s10295-016-1848-1

Yau YK, Ooi CW, Ng EP et al (2015) Current applications of different type of aqueous two-phase systems. Bioresour Bioprocess 2:49. https://doi.org/10.1186/s40643-0150078-0

Zhao Y, Sun S, Hu C et al (2015) Performance of three microalgal strains in biogas slurry purification and biogas upgrade in response to various mixed light-emitting diode light wavelengths. Bioresour Technol 187:338-345. https://doi.org/10.1016/j.biortech.2015.03.130

Zhu C, Zhang R, Cheng L et al (2018) A recycling culture of Neochloris oleoabundans in a bicarbonate-based integrated carbon capture and algae production system with harvesting by auto-flocculation. Biotechnol Biofuels 11:204. https://doi.org/10.1186/s13068-018-1197-6

Publisher's Note Springer Nature remains neutral with regard to jurisdictional claims in published maps and institutional affiliations. 